\title{
ON THE DIELECTRIC CONSTANTS OF MINERALS
}

(The Determinations of Dielectric Constants of Minerals and Rocks $^{25)}$ and their Applications to the Mineralogical and Geological ${ }^{23)}$ Studies, Part 1)

\section{Jitsutaro Takubo, Yasuo Ukai and Satoru Kakitani Geological and Mineralogical Institute, Faculty of Science, University of Kyoto.}

\section{Preface}

The dielectric constants of minerals have been determined by numerous investigators to whom L. Boltzman, ${ }^{2)}$ L. Graetz, ${ }^{\text {) }}$ L. Fomm, W. M. Thornton, 27) J. Curie, ${ }^{3)}$ Th. Liebish, 13) H. Rubens, W. Schmidt, ${ }^{19}$ ) J. Takubo ${ }^{22)}$ are included. W. Schmidt has determined the dielectric constants of various minerals using the immersion method and their values have been hitherto under the most utilization. According to the Maxwell's?) theory, the dielectric constants of non-metallic crystals such as sulfur and diamond which are constructed from a single element are related to the refractive indices by the simple formula as $n^{2}=\varepsilon$. But common ionic crystal exhibits some of the three kinds of polarizations $\left.{ }^{6}\right)$ under the electromagnetic vibration with appropriate frequencies. The maximum dielectric loss owing to the electronic polarization arises on the frequency of visible or infra-violet ray, and that owing to the atomic polarization arises on the infra-red frequency.

In addition to these polarizations, the dipolar substances have orientational polarization due to the orientational displacement of dipole. In the case of common ionic crystals, 24) therefore they should show higher dielectric constants than those obtained by squaring the refractive indices owing to other polarizations beside the electronic one and do not satisfy the Maxwell's formula. Notwithstand- 
ing of this fact, the dielectric constants generally show analogous : changes to those of refractive indices. Therefore, the mineralogical studies which have been carried on by the cieterminations of the refractive indices should be made more effectively by the determinations of the dielectric constants. From the above reasons, the writers dare say that the study of dielectric constant shall be developed to the important researching method of mineralogy in near future.

\section{Measuring methods of dielectric constants}

For the measurements of dielectric constants, two following methods were adopted.

Measurement by ultra short wave-length.22) The Barkhausen and Kurz ${ }^{1)}$ vibration of ultra short wave length such as $101.43 \mathrm{~cm}$. was excited by using a vacuum tube US $6 B$ made by the Japan Wireless
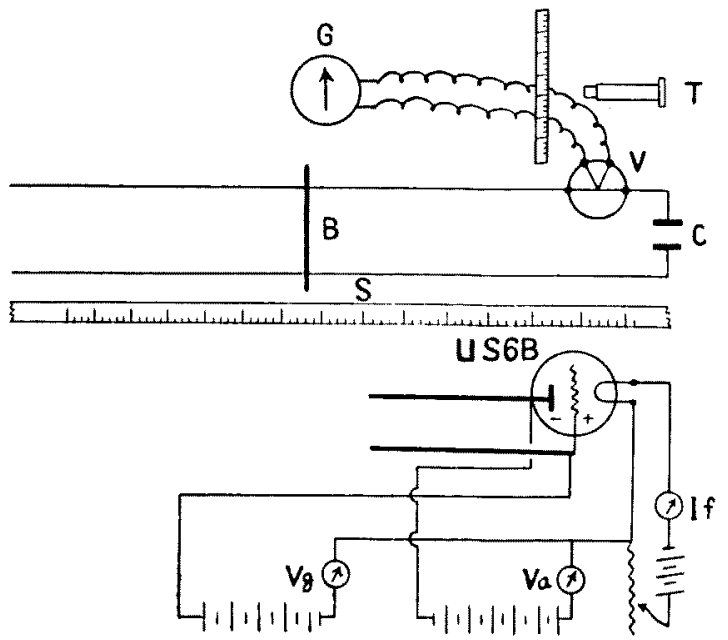

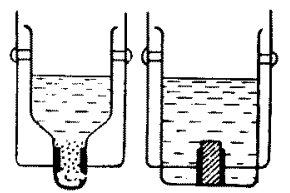

a

b

Fig. 1. Apparatus of Lecher's system by ultra short wave.

$G$ : Galvanometer $S:$ Scale $B$ : Metal Bridge $T:$ Telescope

$V$ : Vacuum Thermo-couple $C$ : Condencer $(\mathrm{a}, \mathrm{b})$

$V_{g}$ : Volt-meter of Grit $V_{a}$ : Volt-meter of Anode

$I_{f}$ : Ampere-meter of Filament. 
Telephony Company and it was resonated with the Lecher's system connerted to a condenser. The exact syntonization may be ascer. tained from the deflection of galvanometer which was connected to a vacuum thermo-couple inserted to Lecher's system. The whole apparatus is indicated in Fig. 1.

The condencer was connected with the parallel lying Lecher wires. Thus a circuit was made, consisting of the Lecher wires, metal bridge and the condenser. The circuit was resonated with the radiated electromagnetic wave by means of sliding the metal bridge and the position of it was read on the scale at just time when the maximum syntonization was ascertained by the deflection of galvanometer. As the standard solution, we used the acetone, benzene and several mixed solutions of them. The scale reading was obtained with the condencer containing suitable amount of a standard solution. After the same procedure was repeated respectively with each standard solution, the curve representing the relation between the scale readings and the dielectric constants of the standard solutions was made. In this way, the operations were undertaken with the condenser containing both the standard solution and the mineral specimen and another curve was made from the thus obtained scale readings. The dielectric constant of the mineral under consideration was determined, corresponding to that of a cross point of these two curves.

The condenser (b) was used for the polished plate and (a), for the powder sample of the mineral.

Measurement by moderate wave length such as $500 \mathrm{kc}^{17}$ ) The measuring apparatus is shown in Fig. 2.

The standard frequency wave excited by the emissioner $(O)$ is syntonized by means of $(L)$ and $\left(L_{c}\right)$. The immersion method was applied as in the case of (A). The condenser $\left(C_{x}\right)$ containing standard solution and mineral may be syntonized by changing the capacity of standard condenser $\left(\mathrm{C}_{\mathrm{s}}\right)$. The dielectric constant of mineral corresponds with that of the intersection of two curves, of 


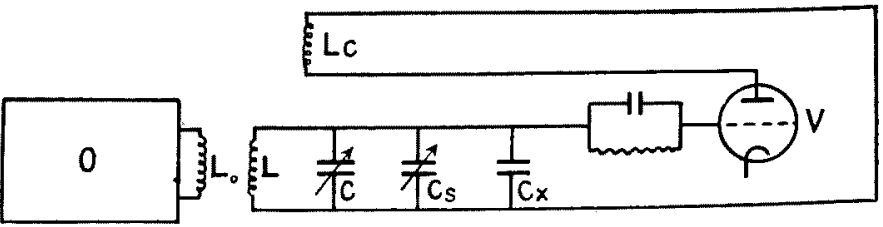

Fig. 2. Measuring apparatus for $500 \mathrm{kc}$. frequency.
0 : Standard ossilator
C: Resonance condenser
$\mathbf{L}_{\mathbf{o}}$ : Ossilation coil
$\mathrm{C}_{\mathrm{s}}:$ Standard condenser
$L$ : Resonance coil
$\mathrm{C}_{\mathbf{x}}$ : Condenser with Sample
$\mathrm{L}_{c}$ : Regeneration coil
$\mathrm{V}$ : Autodyne coherer.

which one curve relates to the dielectric constants of standard solutions and readings of capacities of standard condenser $\left(C_{s}\right)$, and other relates to those obtained by using condenser $\left(C_{x}\right)$ containing a mineral immersed in the standard solution. The cell constant of $\left(C_{x}\right)$ condenser was determined with distilated pure acetone made by Merk Company accepting its dielectric constant as 19.54 at $18^{\circ} \mathrm{C}$. The dielectric constants of mixed standard solutions of acetone and benzene in various proportions were measured by using the determined cell constant. These results are shown in the following Table.

Table 1

\begin{tabular}{c|c|c|c|c|c}
\hline \multirow{2}{*}{ Acetone \% } & \multicolumn{2}{|c|}{$\varepsilon$} & & \multicolumn{2}{|c}{$\varepsilon$} \\
\cline { 2 - 3 } & 1 & 2 & Acetone \% & 1 & 2 \\
\hline \multirow{2}{*}{0} & 2.28 & 2.25 & 35.0 & 7.14 & 7.62 \\
9.8 & 3.52 & 3.49 & 40.0 & 8.01 & 8.23 \\
15.0 & 4.31 & 423 & 45.0 & 8.79 & 9.09 \\
20.0 & 5.05 & 4.98 & 49.5 & 9.81 & 9.90 \\
25.0 & 5.88 & 5.78 & 60.0 & 11.48 & 11.87 \\
31.0 & 6.64 & 6.73 & 69.4 & & 13.85 \\
\hline
\end{tabular}

$\varepsilon$ 1: D. C. determined with $500 \mathrm{kc}$. in frequency

\& 2: D. C. determined with $76 \mathrm{~cm}$. in wave length by $W$. Schmidt20).

\section{Experimental results}

The dielectric constants of various kinds of minerals. With the above mentioned methods, the dielectric constants of various kinds of minerals were determined. The results are summarized as follows. 
Table 2

\begin{tabular}{|c|c|c|c|c|}
\hline Mineral & locality & $\varepsilon(1)$ & $\varepsilon(2)$ & $\varepsilon(3)$ \\
\hline Garnet & Wada-toge, Nagano Pref. & 11.58 & 12.71 & \\
\hline \multirow[t]{5}{*}{ Zincblende } & Ani-mine, Akita Pref. & 7.90 & 7.60 & \\
\hline & $\begin{array}{l}\text { Chichibu-mine, Saitama } \\
\text { Pref. }\end{array}$ & 7.90 & & \\
\hline & $\begin{array}{l}\text { Nakatatsu-mine, Fukui } \\
\text { Pref. }\end{array}$ & 12.13 & & \\
\hline & Zoplin, Misori, U.S.A. & 7.90 & & \\
\hline & Claustal, Harz. & 7.88 & & \\
\hline \multirow[t]{6}{*}{ Fluorite } & $\begin{array}{l}\text { Akenobe-mine, Hyogo } \\
\text { Pref. }\end{array}$ & 6.26 & & \\
\hline & $\begin{array}{l}\text { Aokawa, Wakayama } \\
\text { Pref. }\end{array}$ & & $\left\{\begin{array}{l}6.28 \\
621\end{array}\right.$ & 6.69 \\
\hline & Ikuno-mine, Hyogo Pref. & 6.28 & & \\
\hline & Gonberg, Schweiz. & 6.26 & & \\
\hline & Durham, England. & $\left\{\begin{array}{l}633 \\
6.26\end{array}\right.$ & & \\
\hline & Freiberg, Sachsen & $\left\{\begin{array}{l}6.63 \\
6.58\end{array}\right.$ & & \\
\hline \multirow[t]{2}{*}{ Opal } & Bodai, Ishikawa Pref. & 7.18 & 1810 & \\
\hline & $\begin{array}{l}\text { Hōsaka, Fukushima } \\
\text { Pref. }\end{array}$ & 7.43 & 2230 & \\
\hline Agate & unknown & 7.43 & 44.40 & \\
\hline \multirow[t]{2}{*}{ Rock Salt } & Huetra von Sal & $\left\{\begin{array}{l}5.55 \\
5.55 \\
5.56\end{array}\right.$ & & \\
\hline & Stassfurt, Sachsen & 5.40 & & \\
\hline Hyalite & $\begin{array}{l}\text { Tateyama, Toyama } \\
\text { Pref. }\end{array}$ & $\left\{\begin{array}{l}4.12 \\
4.22\end{array}\right.$ & 451 & \\
\hline Chalcedony & $\begin{array}{l}\text { Tateyama, Toyama } \\
\text { Pref. }\end{array}$ & 5.48 & & \\
\hline Analcime & Seiser Alp. Tirol & $\left\{\begin{array}{l}5.88 \\
5.87\end{array}\right.$ & & \\
\hline Leucite & Albanergebirge, Italy & $\left\{\begin{array}{l}7.08 \\
7.13 \\
7.18\end{array}\right.$ & & \\
\hline \multirow[t]{3}{*}{ Calcite } & $\begin{array}{l}\text { Kamioka-mine, Toyama } \\
\text { Pref. }\end{array}$ & $\perp c$ & Lc 8.15 & 8.35 \\
\hline & & 7.88 & $/ / \mathrm{c} \quad 7.41$ & \\
\hline & $\begin{array}{l}\text { Taio-mine, Fukuoka } \\
\text { Pref. }\end{array}$ & $\perp c$ & & \\
\hline
\end{tabular}


On the Dielectric Constants of Minerals

Table 2-Continued

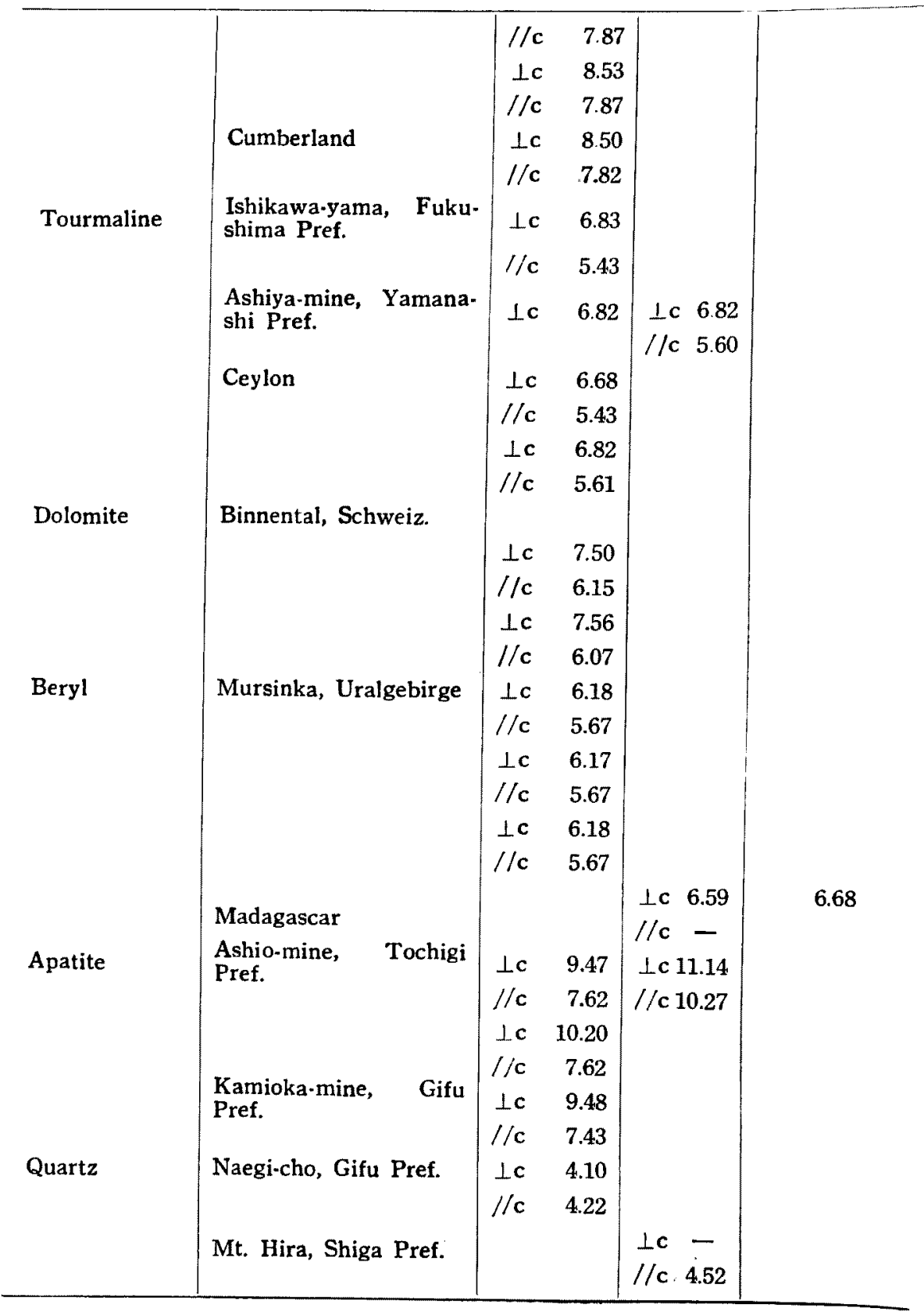


Table 2-Continued

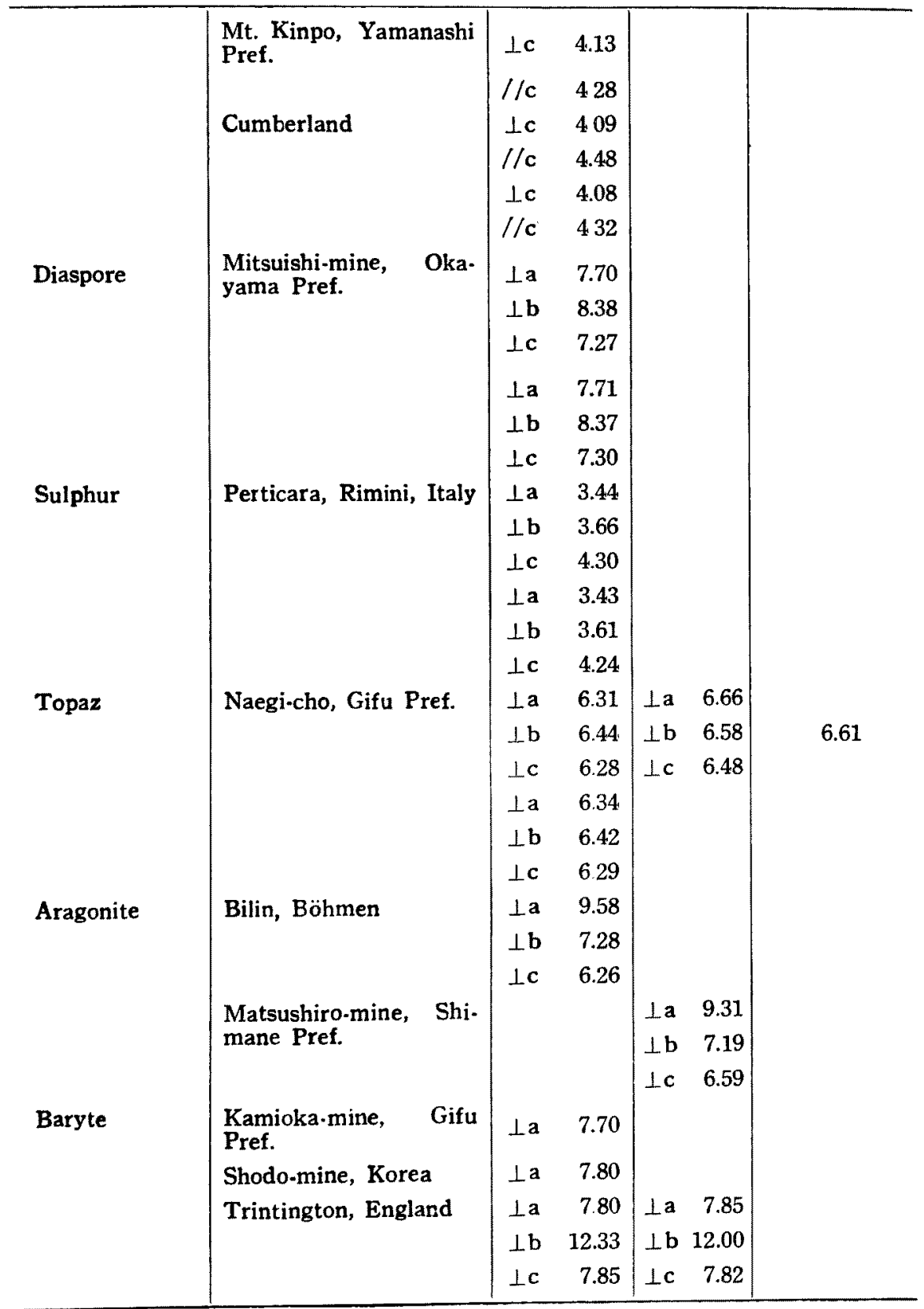


Table $2 \longrightarrow$ Continued

\begin{tabular}{|c|c|c|c|c|}
\hline Celestin & Girgemt, Sizilien & $\begin{array}{ll}\perp \mathrm{a} & 7.58 \\
\perp \mathrm{b} & - \\
\perp \mathrm{c} . & 825 \\
\perp \mathrm{a} & 7.61 \\
\perp_{\mathrm{b}} & - \\
\perp \mathrm{c} & 8.27\end{array}$ & & \\
\hline Damburite & Toroku, Miyazaki Pref. & & $\begin{array}{cc}\perp \mathrm{a} & 6.35 \\
\perp \mathrm{b} & 6.34 \\
\perp \mathrm{c} & 6.58 \\
\perp \mathrm{a} & - \\
\perp \mathrm{b} & 6.34 \\
\perp \mathrm{c} & 6.77\end{array}$ & 6.67 \\
\hline Gypsum & $\begin{array}{l}\text { Hanaoka-mine, Akita } \\
\text { Pref. }\end{array}$ & 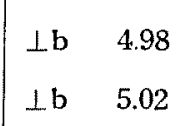 & $\perp \mathrm{b} \quad 5.00$ & \\
\hline Vivianite & $\begin{array}{l}\text { Ashio-mine, Tochigi } \\
\text { Pref. }\end{array}$ & 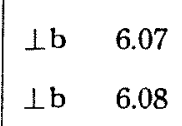 & $\perp$ b $\quad 6.34$ & \\
\hline Epidote & Zalzbachtal, Tirol & $\begin{array}{lr}\varepsilon I & 7.69 \\
\varepsilon \mathbb{I} & 10.11 \\
\varepsilon \mathbb{I I} & 15.39\end{array}$ & & \\
\hline Moonstone & Binzan, Korea & $\begin{array}{l}/ /(100) 5.71 \\
/ /(010) 5.96 \\
/ /(001) 5.71 \\
/ /(100) 5.77 \\
/ /(010) 6.01 \\
/ /(001) 5.76\end{array}$ & & \\
\hline Allanite & $\begin{array}{l}\text { Sandaiko, Manchuria } \\
\text { Mt. Suisho, Fukushima } \\
\text { Pref. } \\
\text { Morimoto, Kyoto Pref. } \\
\text { Angaku, Korea } \\
\text { Tatsurido, Korea }\end{array}$ & & $\begin{array}{l}19.40 \\
19.40 \\
29.10 \\
25.90 \\
16.10 \\
12.50 \\
14.80 \\
15.63\end{array}$ & $\begin{array}{l}10.40 \\
10.90\left(800^{\circ} \mathrm{C}\right) \\
14.10 \\
14.10\left(800^{\circ} \mathrm{C}\right) \\
12.50 \\
14.30\left(800^{\circ} \mathrm{C}\right) \\
17.10 \\
11.20\left(800^{\circ} \mathrm{C}\right) \\
14.00\end{array}$ \\
\hline
\end{tabular}


Table 2-Continued

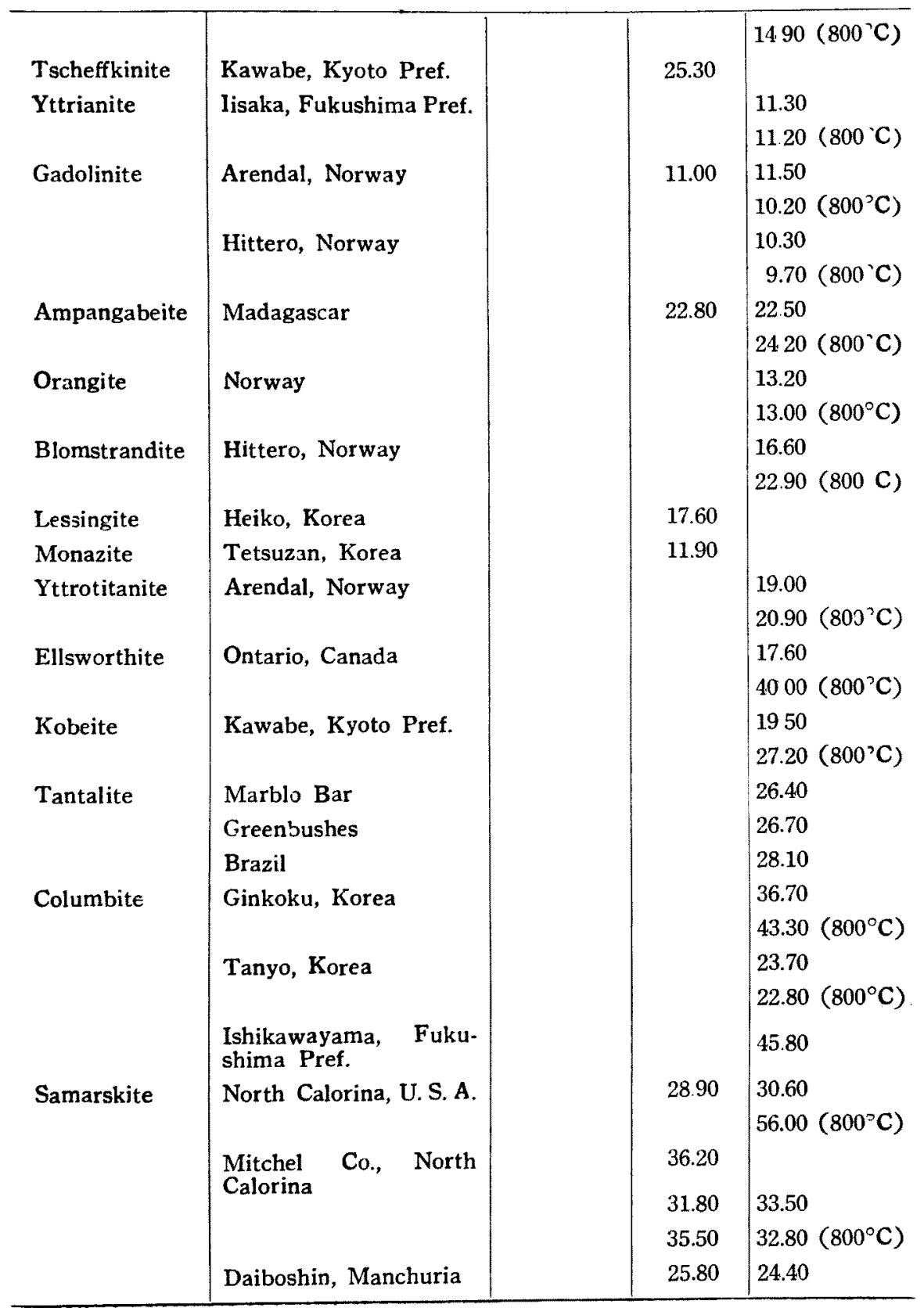


Table 2-Continued

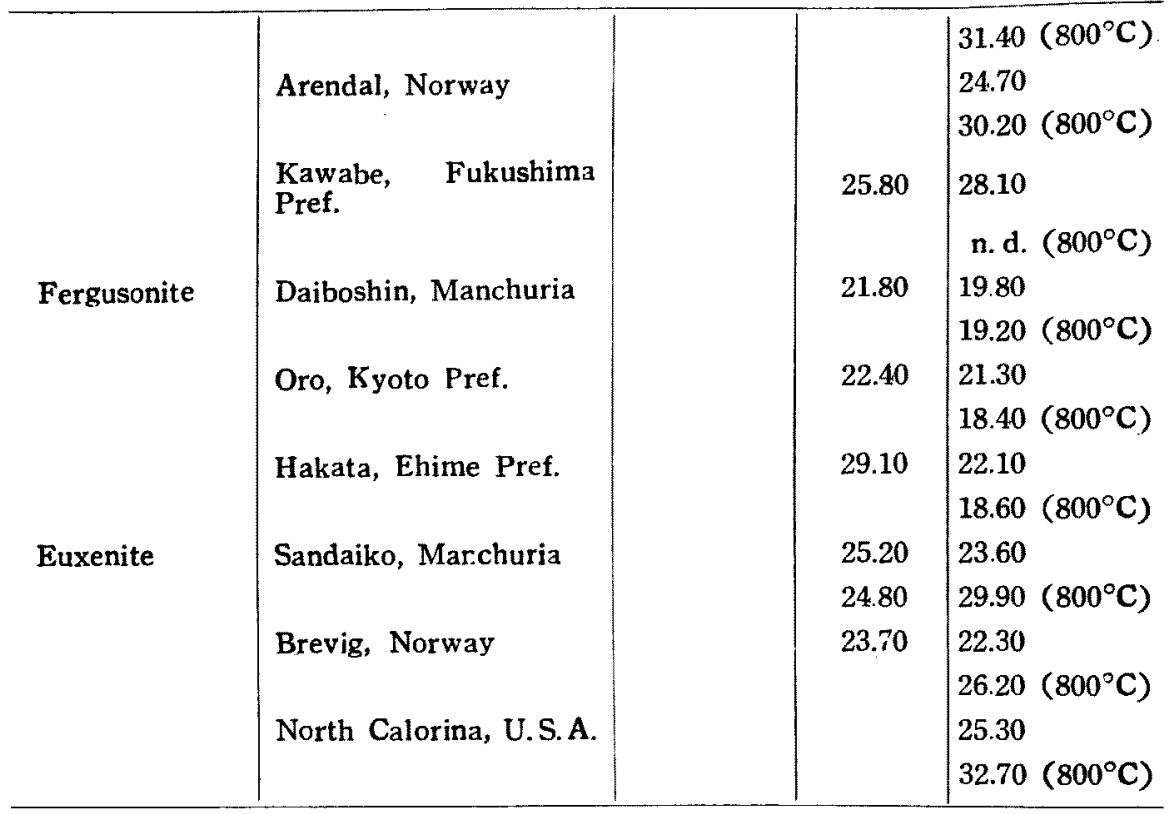

In the above Table, $\varepsilon(1)$ and $\varepsilon(2)$ show the dielectric constants determined respectively with the wave having $101.43 \mathrm{~cm}$. in length and $500 \mathrm{kc}$. wave using a thin plate of the mineral, and $\varepsilon(3)$ those of the powder specimens pulverized into 80-100 mesh with $500 \mathrm{kc}$. wave. The dielectric constants of massive specimens having no defined crystal faces or of fine grained specimens which can not be polished into thin plates were measured with pulverized powders. $\perp a, \perp b$ and $\perp c$ stand for the thin plates perpendicular to crystal axes $a, b$ and $c, / / a, / / b$ and $/ / c$ the parallel sections to each axis and $/ /(100), / /(010)$ and $/ /(001)$ the parallel sections to the crystal faces (100), (010), (001). On the metamict minerals, measurements were made either with the original and crystallized specimens which were preheated at $800^{\circ} \mathrm{C}$.. These values of the latter are distinguished from those of former by denoting $800^{\circ} \mathrm{C}$.. According to the above described results, no remarkable difference can be recognized between the two dielectric constants which were measured with 
ultra short wave $101.43 \mathrm{~cm}$. and intermediate frequency wave 500 kc.. But on the dielectric constants measured by $500 \mathrm{kc}$. wave, the hydrated amorphous or cryptocrystalline minerals such as opal, agate show, however, more significant high dielectric constants than that of non-hydrated quartz. This phenomena ${ }^{26)}$ should be ascribed to the orientational polarization of dipole substances. The minerals having the complicated chemical composition such as allanite, tantalite, columbite, samarskite, fergusonite, euxenite and etc. show remarkably higher dielectric constants than those of common silicate minerals and the values of same species are different according to their localities. These facts should be ascribed to the discrepancies of minute chemical compositions according to their localities or to the additions of some dipole substances. The dielectric constants of the preheated metamict minerals differ from those of non-heated metamict minerals; some increase their values and others decrease.

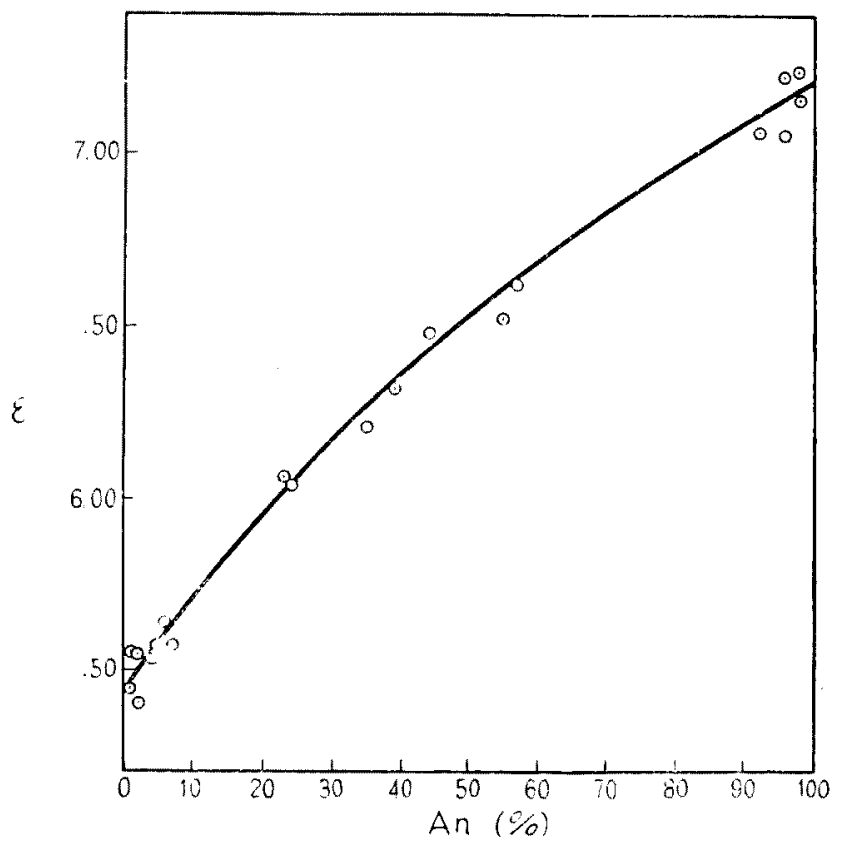

Fig. 3. Relationship between dielectric constant and An-content of plagioclase. 


\begin{tabular}{|c|c|c|c|c|c|c|c|}
\hline 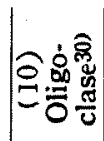 & 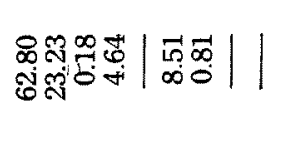 & 둘 & $\overbrace{0}^{\circ}$ & 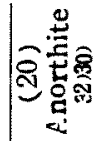 & 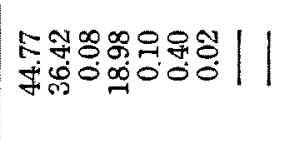 & 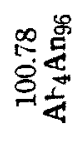 & ถู \\
\hline 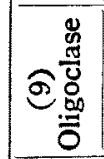 & 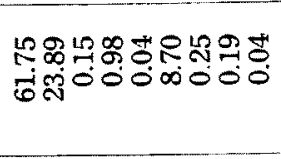 & 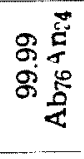 & $\begin{array}{l}3 \\
0\end{array}$ & 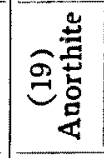 & 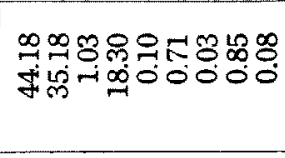 & $\oint_{0}^{0} \frac{8}{5}$ & $\stackrel{5}{\circ}$ \\
\hline 事产 & 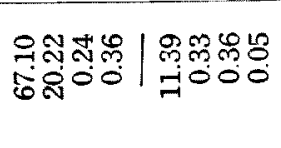 & $\begin{array}{l}\ln \\
8 \\
8\end{array}$ & $\begin{array}{l}\text { 안 } \\
\text { L }\end{array}$ & 孪总 & 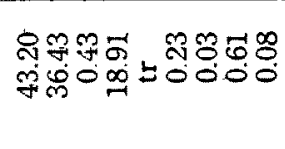 & 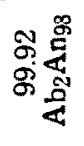 & $\stackrel{10}{2}$ \\
\hline E: & 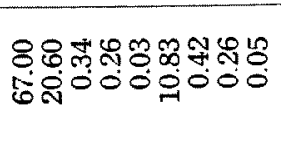 & $\begin{array}{l}g \vec{E} \\
\dot{8} \\
\dot{8}\end{array}$ & $\begin{array}{l}10 \\
107 \\
10\end{array}$ & 点总 & 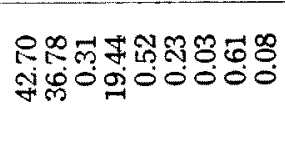 & 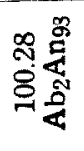 & 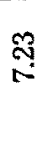 \\
\hline 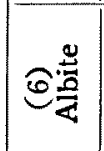 & 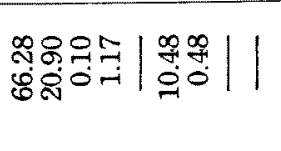 & 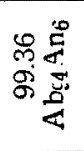 & $\begin{array}{l}\vec{~} \\
\text { is }\end{array}$ & 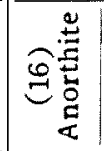 & 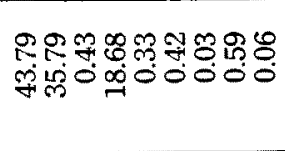 & 象总道 & ${ }_{10}^{10}$ \\
\hline 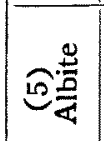 & 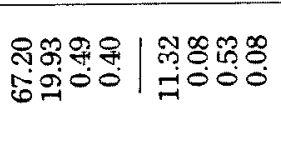 & 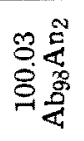 & $\begin{array}{l}10 \\
10 \\
10\end{array}$ & in & 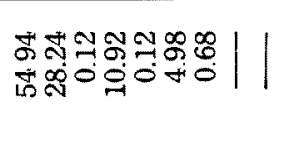 & 乐总 & 莒 \\
\hline ङ롤 & 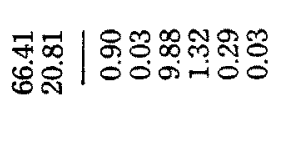 & 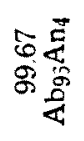 & Bo & 至总总 & 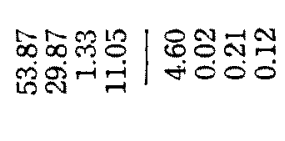 & ㄷㅇㅇ룰 & 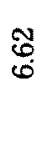 \\
\hline ชิ & 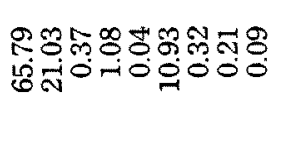 & $\begin{array}{l}0 \\
0 \\
8 \\
8 \\
5\end{array}$ & $\begin{array}{l}\infty \\
10 \\
10\end{array}$ & 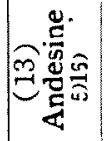 & 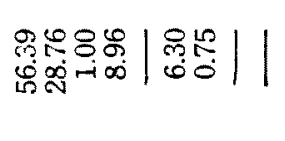 & 突葋 & $\underset{0}{0}$ \\
\hline ลิ: & 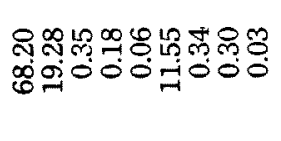 & $\begin{array}{l}8 \bar{E} \\
8 \\
8 \\
8\end{array}$ & $\begin{array}{l}\text { if } \\
\text { is }\end{array}$ & ○ิ & 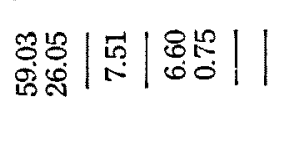 & 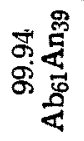 & ") \\
\hline 突蒂 & 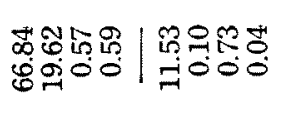 & 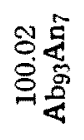 & ס & છ莺 & 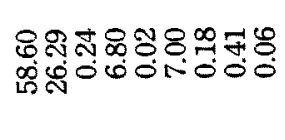 & $\frac{8}{8} \frac{8}{8}$ & هి \\
\hline$\stackrel{\dot{0}}{\dot{B}}$ & 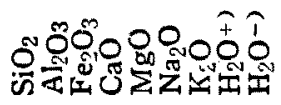 & $\underset{0}{\overrightarrow{0}}$ & $w$ & $\stackrel{\dot{\Xi}}{\mathrm{E}}$ & 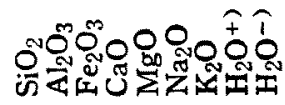 & $\underset{0}{\overrightarrow{0}}$ & $\omega$ \\
\hline
\end{tabular}


Dielectric constants of rock forming minerals. The chemical compositions and dielectric constants of common rock forming minerals such as plagioclase-, pyroxene-, amphibole-group minerals were determined. The dielectric constants of these minerals were measured with pulverized powders.

Plagioclase-group. The chemical compositions and dielectric constants are shown in Table 3 and An \%-ع diagram is shown in Fig. 3. The relationship between the dielectric constants and An-contents Table 4-1

\begin{tabular}{|c|c|c|c|c|c|c|c|}
\hline Comp. & (1) & (2) & (3) & (4) & (5) & (6) & (7) \\
\hline $\mathrm{SiO}_{2}$ & 57.25 & 47.89 & 52.82 & 44.77 & 50.58 & 39.39 & 49.59 \\
\hline $\mathrm{Al}_{2} \mathrm{O}_{3}$ & 2.65 & $\longrightarrow$ & 18.02 & 7.67 & 4.24 & 11.29 & 1.14 \\
\hline $\mathrm{Fe}_{2} \mathrm{O}_{3}$ & 3.73 & 10.01 & 3.08 & 4.07 & 4.36 & 12.99 & $\longrightarrow$ \\
\hline $\mathrm{FeO}$ & 421 & 2.89 & 4.74 & 4.18 & $\longrightarrow$ & 4.12 & 23.76 \\
\hline $\mathrm{CaO}$ & 2.02 & 0.82 & 3.69 & 24.35 & 22.69 & 29.46 & 22.13 \\
\hline $\mathrm{MgO}$ & 29.25 & 35.08 & 17.70 & 14.81 & 17.23 & 3.76 & 1.64 \\
\hline $\mathrm{K}_{2} \mathrm{O}$ & $\begin{array}{r}\mathrm{TiO}_{2} \\
0.10\end{array}$ & & & & & & $\begin{array}{r}\mathrm{MnO} \\
1.48\end{array}$ \\
\hline $\mathrm{Na}_{2} \mathrm{O}$ & - & 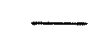 & - & - & 0.44 & - & 0.45 \\
\hline $\left.\mathrm{H}_{2} \mathrm{O}^{-}\right)$ & $\longrightarrow$ & 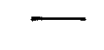 & $\longrightarrow$ & - & 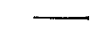 & - & - \\
\hline $\mathrm{H}_{2} \mathrm{O}^{+)}$ & 0.35 & 4.01 & 0.34 & 0.15 & - & 0.41 & - \\
\hline Total & 99.56 & 100.70 & 100.39 & 100.00 & 99.54 & 101.42 & 100.19 \\
\hline Comp. & (8) & (9) & (10) & (11) & (12) & (13) & \\
\hline $\mathrm{SiO}_{2}$ & 50.07 & 53.56 & 50.18 & 51.00 & 63.25 & 51.77 & \\
\hline $\mathrm{Al}_{2} \mathrm{O}_{3}$ & - & 0.26 & 2.80 & 12.41 & 27.65 & 6.71 & \\
\hline $\mathrm{Fe}_{2} \mathrm{O}_{3}$ & - & 2.75 & - & 2.27 & 0.53 & $\longrightarrow$ & \\
\hline $\mathrm{FeO}$ & 24.04 & 8.69 & 12.50 & 8.05 & 0.42 & 1.27 & \\
\hline $\mathrm{CaO}$ & 21.41 & 30.16 & 17.79 & 14.49 & 0.83 & 37.92 & \\
\hline $\mathrm{MgO}$ & 3.25 & 1.70 & 13.54 & 6.32 & $\longrightarrow$ & . & \\
\hline $\mathbf{K}_{2} \mathbf{O}$ & & - & & 0.23 & 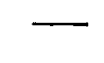 & & \\
\hline $\mathrm{Na}_{2} \mathrm{O}$ & . & 2.64 & - & 5.12 & 1.35 & 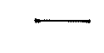 & \\
\hline $\mathrm{H}_{2} \mathrm{O}^{-)}$ & & & & & 5.81 & $\longrightarrow$ & \\
\hline $\mathrm{H}_{2} \mathrm{O}^{+)}$ & 0.33 & - & 1.02 & 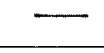 & 0.23 & 1.03 & \\
\hline Total & 99.10 & 99.76 & 97.83 & 99.89 & 100.07 & 98.70 & \\
\hline
\end{tabular}


On the Dielectric Constants of Minerals

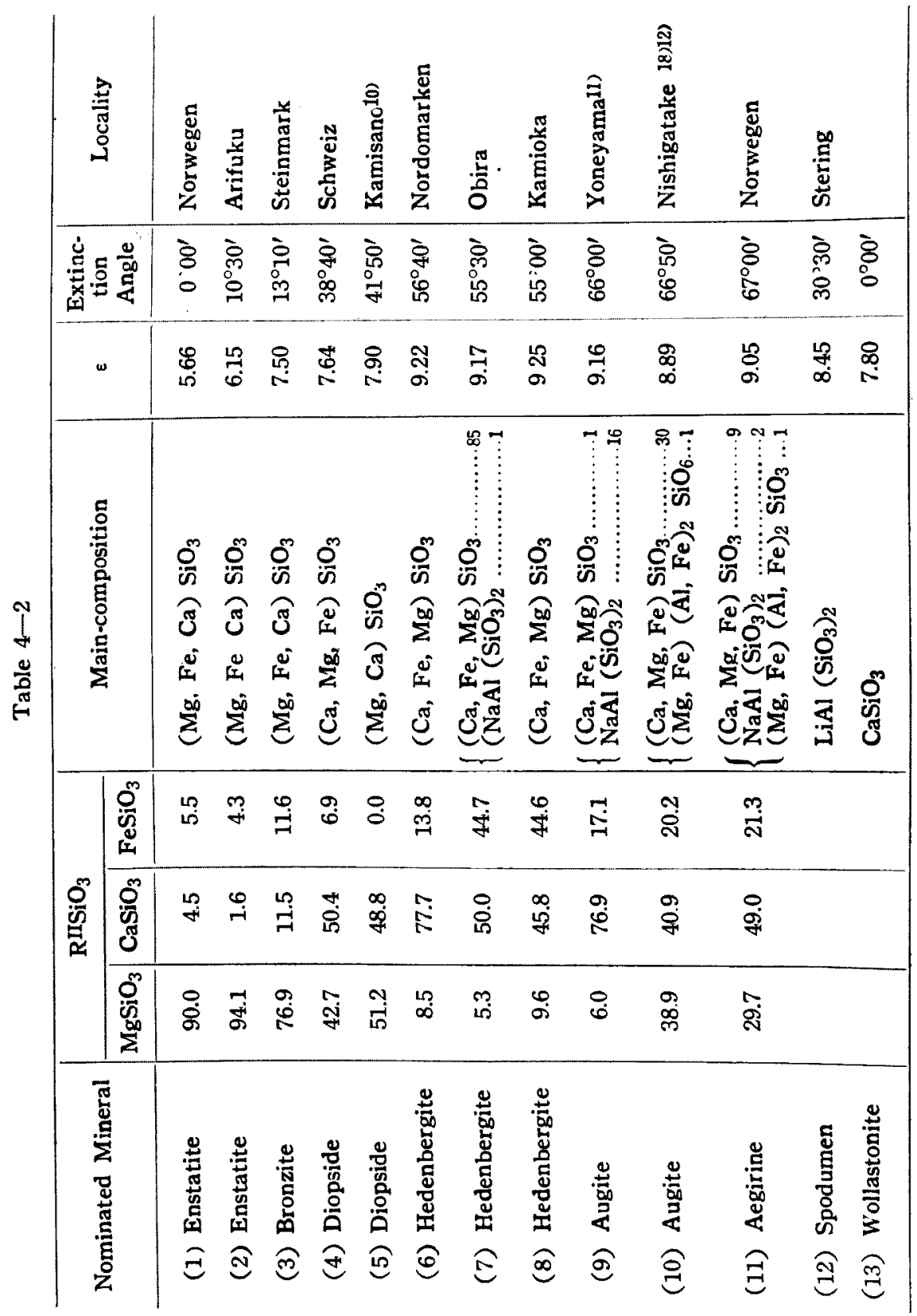


of plagioclases can be shown by the following formula, $\varepsilon=5.473$ $( \pm 0.016)+0.00241( \pm 0.00010) \mathrm{An}-0.000070( \pm 0.000010) \mathrm{An}^{2}$. Where An denotes the contents of anorthite by percentage. From this experimental formula, the An contents may be easily calculated by measuring the dielectric constant without chemical analysis or microscopic determination.

Pyroxene-group(4),31,4),21),15). The chemical compositions and dielectric constants of pyroxene-group minerals are indicated in Table 4-1 and Table 4-2.

The molecular percentage of $\mathrm{MgSiO}_{3}$ and $\varepsilon$ are related in Fig. 4.

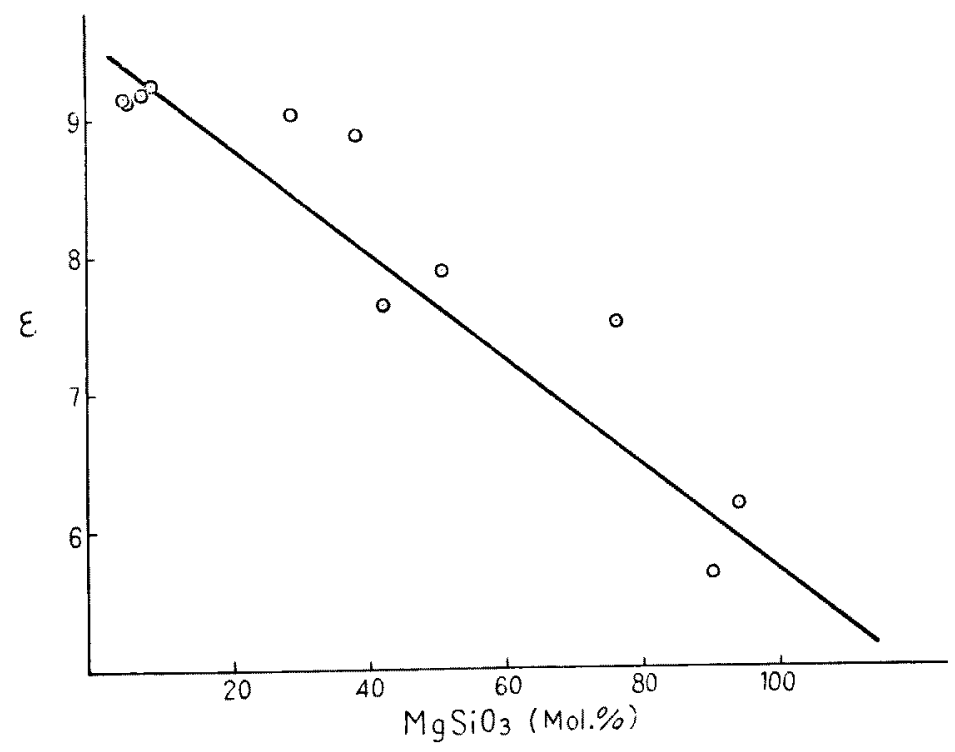

Fig. 4. $\varepsilon \cdot \mathrm{MgSiO}_{3}$ content diagram of pyroxene.

The increase of molecular percentage of $\mathrm{MgSiO}_{3}$ proportionally decreases the dielectric constants of minerals. The dielectric constants of pyroxenes which contain $\mathrm{MgSiO}_{3}$ less than $17 \%$ are above 9. $\mathrm{MgSiO}_{3} 17-44 \%$ show 9-8, $\mathrm{MgSiO}_{3} 44-72 \%$ 8-7, $\mathrm{MgSiO}_{3} 72-100 \%$ lower than 7. The $\mathrm{CaSiO}_{3}$ and $\mathrm{FeSiO}_{3}$ components present almost no different influence upon the dielectric constant of pyroxene. Accepting the facts that the dielectric constant of pyroxene is 
remarkably effected by the $\mathrm{MgSiO}_{3}$ component and have no different influence by $\mathrm{CaSiO}_{3}$ or $\mathrm{FeSiO}_{3}$, the three components and $\varepsilon$ of pyroxene-group minerals are related as the following diagram.

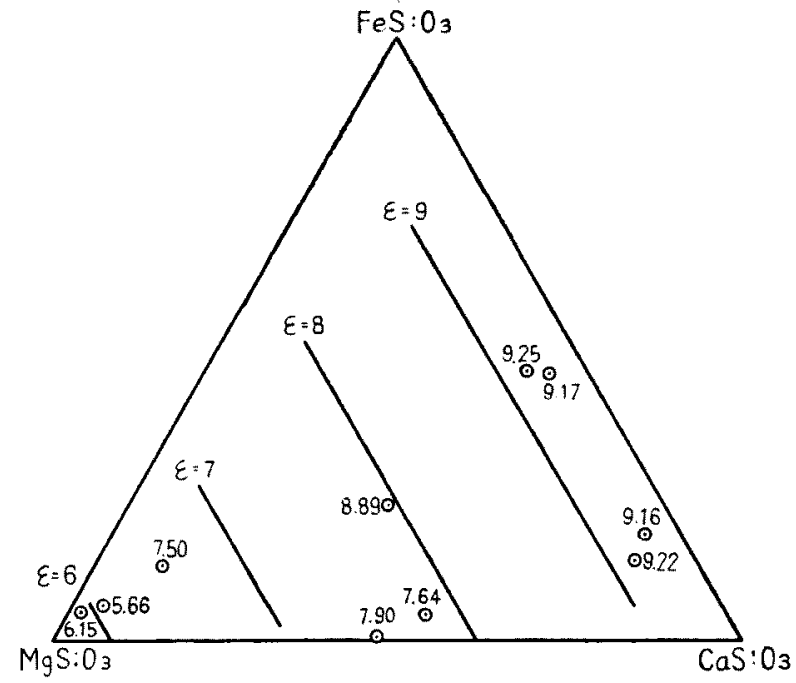

Fig. 5. Diagram showing the relation of three components $\left(\mathrm{MgSiO}_{3}, \mathrm{CaSiO}_{3}, \mathrm{FeSiO}_{3}\right)$ and $\mathrm{e}$.

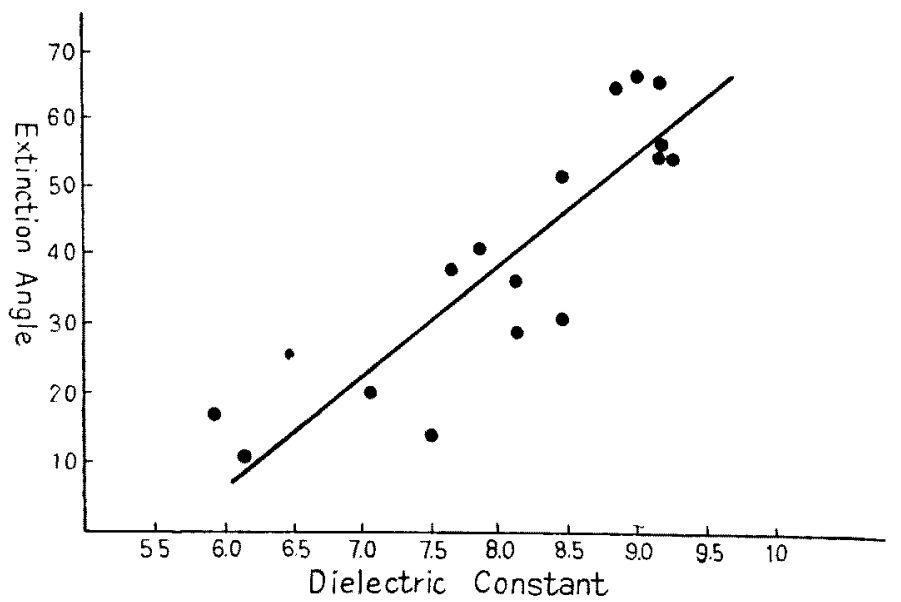

Fig. 6. Relationship between dielectric constant and extinction angle of pyroxene. 
Wollastonite differs in the crystal structure from other pyroxene minerals and shows lower dielectric constant notwithstanding its negligible small amount of $\mathrm{MgSiO}_{3}$ component. On the alkali-bearing pyroxene, the dielectric constant of jadate is lower than that of spodumen and that of aegirine is relatively high. As is shown in Fig. 6 showing the relation between the extinction angles and dielectric constants, the increase of extinction angle shows a tendency to increase the dielectric constants.

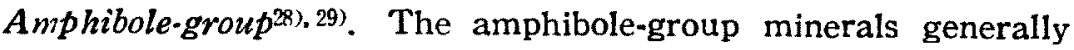
contain more $\mathrm{R}_{2}{ }^{\mathrm{III}} \mathrm{O}_{3}, \mathrm{R}_{2} \mathrm{IO}$ and $\mathrm{H}_{2} \mathrm{O}$ components comparing with the pyroxene-group minerals. Accordingly, these components should be accounted for the dielectric constants of amphiboles. From the analytical results, the molecular ratio $\mathrm{R}_{2}{ }^{\mathrm{I} O}: \mathrm{R}^{\mathrm{II} O}: \mathrm{R}_{2}{ }^{\mathrm{III}} \mathrm{O}_{3}: \mathrm{H}_{2} \mathrm{O}$ and $\mathrm{MgSiO}_{3}: \mathrm{CaSiO}_{3}: \mathrm{FeSiO}_{3}$ were calculated and these values as well as the dielectric constants and extinction angles of these minerals are shown in Table 5.

Table 5

\begin{tabular}{|c|c|c|c|c|c|c|c|c|c|}
\hline \multirow{2}{*}{$\begin{array}{l}\text { Nominated. } \\
\text { Mineral }\end{array}$} & \multirow{2}{*}{$\mathrm{R}_{2} \mathrm{I} \mathbf{O}$} & \multirow{2}{*}{ RIIO } & \multirow{2}{*}{$\mathrm{R}_{2} \mathrm{IIIO}_{3}$} & \multirow{2}{*}{$\mathrm{H}_{2} \mathrm{O}$} & \multicolumn{3}{|c|}{$\mathrm{RIISiO}_{3}$} & \multirow[b]{2}{*}{ 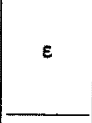 } & \multirow{2}{*}{$\begin{array}{l}\text { Ext. } \\
\text { Angle }\end{array}$} \\
\hline & & & & & $\begin{array}{l}\mathrm{Mg} \\
\mathrm{SiO}_{3}\end{array}$ & $\begin{array}{l}\mathrm{Ca} \\
\mathrm{SiO}_{3} \\
\end{array}$ & $\begin{array}{l}\mathrm{Fe} \\
\mathrm{SiO}_{3} \\
\end{array}$ & & \\
\hline 1 Actinolite & & 82.42 & 4.45 & 13.13 & 63.68 & 27.19 & 9.13 & 6.23 & $15^{\circ} 30^{\prime}$ \\
\hline 2 Actinolite & & 89.85 & 2.58 & 7.57 & 60.31 & 25.26 & 14.43 & 6.60 & $17^{\circ} 30^{\prime}$ \\
\hline 3 Tremolite & & 68.61 & 20.23 & 11.16 & 6.85 & 85.38 & 7.77 & 8.65 & $27^{\circ} 40^{\prime}$ \\
\hline 4 Tremolite & & 82.19 & 17.30 & 0.51 & 29.46 & 69.20 & 1.34 & 6.80 & \\
\hline 5 Tremolite & & 84.05 & 11.76 & 4.19 & 75.64 & 24.36 & & 5.95 & $16^{\circ} 50^{\prime}$ \\
\hline 6 Hornblende & & 63.24 & 19.16 & 17.60 & 32.64 & 32.40 & 34.96 & 8.90 & $40^{\circ} 30^{\prime}$ \\
\hline 7 Hornblende & 3.93 & 83.15 & 4.58 & 8.34 & 59.64 & 24.71 & 15.65 & 7.15 & $19^{\circ} 50^{\prime}$ \\
\hline 8 Hornblende & & 62.83 & 22.80 & 14.37 & 39.39 & 41.89 & 18.72 & 7.11 & $24^{\circ} 10^{\prime}$ \\
\hline 9 Hornblende & & 70.08 & 14.01 & 15.91 & 33.97 & 33.32 & 32.71 & 7.90 & $25^{\circ} 20^{\prime}$ \\
\hline 10 Hornblende & 5.36 & 66.53 & 25.68 & 2.43 & 58.44 & 3827 & 3.29 & 8.45 & $25^{\circ} 20^{\prime}$ \\
\hline 11 Hornblende & & 64.01 & 20.10 & 15.89 & 50.07 & 37.27 & 12.66 & 10.40 & $37^{\circ} 40^{\prime}$ \\
\hline 12 Hornblende & & 70.49 & 20.08 & 9.43 & 52.56 & 3583 & 11.61 & 8.55 & $28^{\prime} 50^{\prime}$ \\
\hline 13 Hornblende & & 65.25 & 17.01 & 17.74 & 5.53 & 30.69 & 63.78 & 7.85 & - \\
\hline 14. Riebeckite & 24.34 & 53.26 & 19.74 & 2.66 & 16.94 & 0.00 & 83.06 & 7.23 & $63^{\circ} 00^{\prime}$ \\
\hline
\end{tabular}


The dielectric constants of amphibole minerals change their values according to the ratio of $\mathrm{MgO},(\mathrm{Ca}, \mathrm{Fe}) \mathrm{O},(\mathrm{Fe}, \mathrm{Al})_{2} \mathrm{O}_{3}, \mathrm{Na}_{2} \mathrm{O}$ and $\mathrm{H}_{2} \mathrm{O}$ contents. Of these components, $\mathrm{H}_{2} \mathrm{O}$ is almost always contained and $\mathrm{Na}_{2} \mathrm{O}$ is negligible excepting some special minerals, so that the ratio $\mathrm{MgO}:(\mathrm{Ca}, \mathrm{Fe}) \mathrm{O}:(\mathrm{Al}, \mathrm{Fe})_{2} \mathrm{O}_{3}$ of each minerals were calculated in the next Table.

Table 6

\begin{tabular}{c|c|c|c|l}
\hline Nominated Mineral & $(\mathrm{Al}, \mathrm{Fe})_{2} \mathrm{O}_{3}$ & $(\mathrm{Fe}, \mathrm{Ca}) \mathrm{O}$ & $\mathrm{MgO}$ & \multicolumn{1}{|l}{ Locality } \\
\hline 1 Actinolite & 5.19 & 39.85 & 48.36 & Daishōji \\
2 Actinolite & 7.55 & 21.81 & 45.89 & Mähren \\
3 Tremolite & 23.33 & 58.78 & 3.09 & Nagahara \\
4 Tremolite & 34.25 & 29.34 & 36.41 & Tessin \\
5 Tremolite & 12.48 & 27.07 & 60.45 & Anto, China \\
6 Hornblende & 41.25 & 44.93 & 13.81 & Mushiana \\
7 Hornblende & 10.25 & 45.84 & 43.91 & Norwegen \\
8 Hornblende & 44.79 & 38.09 & 17.12 & Fukuoka33) \\
9 Hornblende & 36.39 & 48.00 & 15.59 & Schweisberg \\
10 Hornblende & 49.98 & 25.14 & 24.88 & Böhmen \\
11 Hornblende & 44.39 & 33.24 & 22.37 & Taihoku \\
12 Hornblende & 45.37 & 30.90 & 23.73 & Nitatōge \\
13 Hornblende & 36.99 & 60.86 & 2.15 & Norwegen \\
14 Riebeckite & 53.76 & 40.65 & 5.59 & Portuga \\
\hline
\end{tabular}

The dielectric constants of amphibole minerals are so effected by their high contents of $\mathrm{R}_{2}{ }^{\mathrm{II}} \mathrm{O}_{3}$ as is shown in Table 5, that there is no regular relationship between the $\mathrm{R}^{\mathrm{II} O} \mathrm{O}$ components and $\varepsilon$ excluding the $\mathrm{R}_{2}{ }^{\mathrm{III}} \mathrm{O}_{3}$ components. From Table 6 these three components are related to the dielectric constants as diagrammatically shown in Fig. 7.

It is noticeable that three kinds of mineral groups are distinguished among the amphibole minerals; two groups are plotted on the broken lines and the other is not belonged to these group. The minerals of the first group which contain relatively small amounts of $\mathrm{R}_{2} \mathrm{O}_{3}$ and over than $80 \%$ of $\mathrm{R}^{\mathrm{II} O}$ consisted with $24-27 \% \mathrm{CaO}$ are 
shown by a general formula $\mathrm{H}_{2} \mathrm{O} \cdot 2 \mathrm{CaO} \cdot 5(\mathrm{Mg}, \mathrm{Fe}) \mathrm{O} \cdot 8 \mathrm{SiO}_{2}$ corresponding to the tremolite-actinolite series in amphibole-group. The dielectric constants of these minerals increase proportionately. with the decrease of $\mathrm{MgO}$ or increase of $\mathrm{FeO}$. On the contrary, the minerals of the second group contain $30-40 \%$ of $\mathrm{CaO}$ and larger amount of $\mathrm{R}_{2}{ }^{\mathrm{III}} \mathrm{O}_{3}$ component than those of the first group, so that the effects of $\mathrm{R}_{2}{ }^{\mathrm{IIO}} \mathrm{O}_{3}$ component upon dielectric constant must be considered. As in the Fig. 7, the minerals of the second group also show a regular relationship between the dielectric constants and three components by considering the $\mathrm{R}_{2}{ }^{\mathrm{III}} \mathrm{O}_{3}$ component. Generally, the $\mathrm{R}_{2}{ }^{I I I} \mathrm{O}_{3}$ components enlarge the dielectric constant more than the $(\mathrm{Ca}, \mathrm{Fe}) \mathrm{O}$ components in $\mathrm{R}^{\mathrm{IIO}}$ do. Other minerals which do not belong to these two groups are alkali-bearing amphible or significantly weathered minerals which show no characteristic properties of amphibole. The alkali-bearing amphiboles have relatively low dielectric constants. Therefore the direct relation between

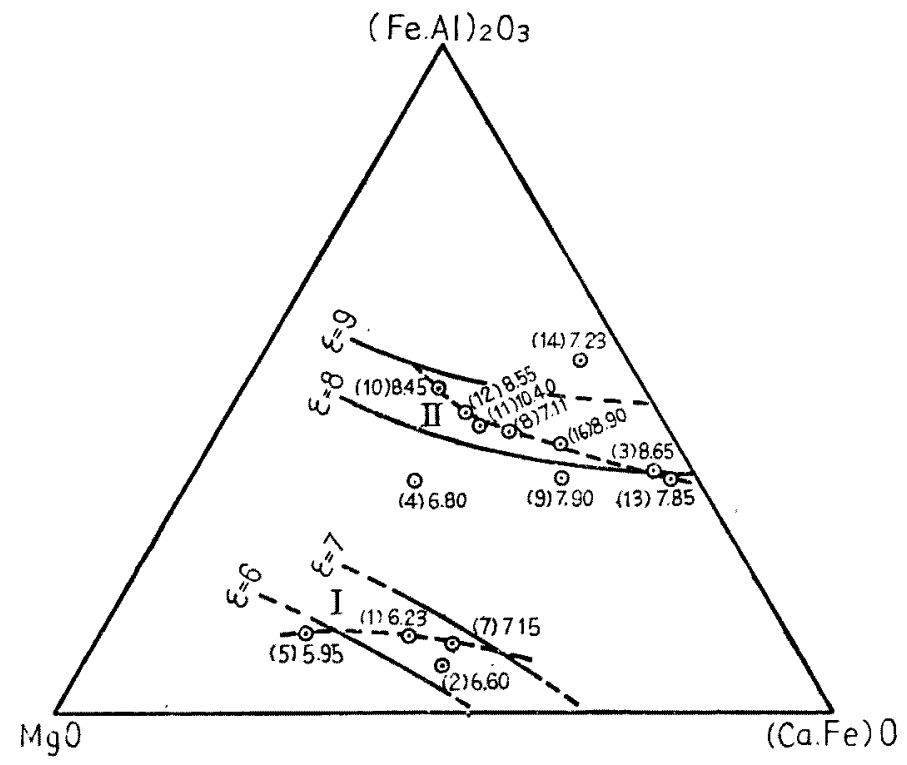

Fig. 7. Diagram showing the relation of three components $\mathrm{MgO},(\mathrm{Ca}, \mathrm{Fe}) \mathrm{O},(\mathrm{Fe}, \mathrm{Al})_{2} \mathrm{O}_{3}$ and $\varepsilon$. 
MgO-contents and dielectric constants was not recognized on the amphibole minerals. On the other hand, the amphibole minerals have more regular relations than pyroxene minerals considering the extinction angles and dielectric constants as shown in Fig. 8. The higher the dielectric constant is, the larger the extinction angle is.

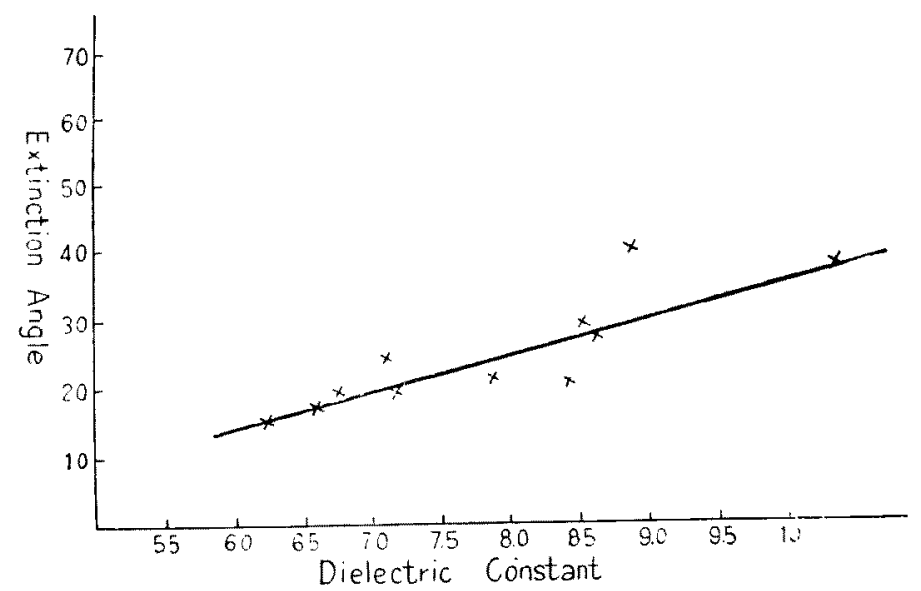

Fig. 8. Relationship between dielectric constant and extinction angle of amphibole.

\section{Résumé}

(1) The dielectric phenomena of minerals are derived from the atomic and electronic polarizations and with some minerals orientational polarizations arise on an adequate magnetic frequency wave. No remarkable difference can be recognized between the two dielectric constants which were measured with ultra short wave having the wave length $101.43 \mathrm{~cm}$. and with intermediate wave having $500 \mathrm{kc}$. with the exceptions of hydrated minerals such as opal and agate.

(2) A relationship between the dielectric constants and An contents of plagioclases can be shown by the experimental formula, $\varepsilon=5.473( \pm 0.016)+0.00241( \pm 0.00010)$ An-0.000070 $( \pm 0.000010) \mathrm{An}^{2}$. From this formula, the An contents of plagioclase may be obtained by determing the dielectric constant. 
(3) The component of $\mathrm{MgSiO}_{3}$ is so related to the dielectric constant of pyroxene mineral as the decrease of its contents inverse proportionally increase the constant. The $\mathrm{CaSiO}_{3}$ and $\mathrm{FeSiO}_{3}$ components show almost no different influence on the dielectric constants.

(4) The tremolite-actinolite series which contain relatively small amount of $\mathrm{R}_{2}{ }^{\mathrm{III}} \mathrm{O}_{3}$ and $\mathrm{CaO}$ component, increase their dielectric constants according to the increase of $\mathrm{FeO}$ or decrease of $\mathrm{MgO}$ component as like the pyroxene minerals. On the other hand, some varieties of amphiboles, containing a large amount of $\mathrm{R}_{2} \mathrm{IIIO}_{3}$ components, show no regular relationship between the dielectric constants and merely $\mathrm{R}^{\mathrm{II} O} \mathrm{O}$ components, while a regularity between the components $\mathrm{MgO},(\mathrm{Ca}, \mathrm{Fe}) \mathrm{O},(\mathrm{Al}, \mathrm{Fe})_{2} \mathrm{O}_{3}$ and dielectric constants was found.

(5) The extinction angles are also intimately related to the dielectric constants of these minerals. The increase of extinction angle is followed by its high dielectric constant.

(6) The dielectric constants of minerals change their values according to the chemical constitutions and crystal structures. So it was an important problem to solve the close relations between the chemical compositions and dielectric constants of isomorphous minerals.

The present writers have been encouraged to promote this new research in the mineralogy.

\section{Acknowledgements}

The writers wish to express their acknowledgements to Mr. Junosuke Masutomi for supplying several specimens and are indebted to the scientific research fund of the Educational Department.

\section{REFERENCES}

1) Barkhausen, H. and K. Kurz: Phy. Zeit.. 91 (1920).

2) Boltzman L.: Pogg. Ann., 151 (1874), 153 (1874), 155 (1875).

3) Curie, J.: Ann. Chem. Phy., (6) 17 (1889). 
4) Deer, W. A. and L. R. Wager: Min. Mag., 5 (1938).

5) Endo, K. and S. Kozu: Jour. Japanese Association of Mineralogists, Petrologists and Economic Geologists, 14 (1935).

6) Frank F. C.: Trans. Farady Soc., 33 (1937).

7) Frohlich H.: Theory of dielectrics, Oxford University, (1949).

8) Graetz, L. and L. Fomm: Wied, Ann, 3 (1895).

9) Harada T.: Japanische Inseln, 50 (1890).

10) Kozu, S., M. Setokuni and J. Ueda: Chikyu, 6 (1928).

11) Kuno, H.: Jour. Geol. Soc. Japan, 42 (1940).

12) Kuno, H.: Jour. Geol. Soc. Japan, 45 (1943).

13) Liebish, Th. and H. Rubens: Berlin Sitzber., 198, 876 (1915), 211 (1921).

14) Machatschki F.: Zeit. Krist., 71 (1929).

15) Matsumoto, H.: Jour. Japanese Association of Mineralogists, Petrologists and Economic Geologists, 36 (1952).

16) Minami, E. and T. Ito: Jour. Japanese Association of Mineralogists, Petrologists, and Economic Geologists, 5 (1931).

17) Mizushima, S. and S. Kubo: Jour. Chem. Soc. Japan, 62 (1941).

18) Ohashi, R.: Jour. Geol. Soc. Japan, 42 (1940).

19) Schmidt, W.: Ann. Phy., 9 (1902).

20) Schmidt, W.: Ann. Phy., 11 (1903).

21) Takahashi, J. and J. Kitahara : Jour. Japanese Association of mineralogists, Petrologists and Economic Geologists, 35 (1951).

22) Takubo, J.: Mem. Coll. Sci., Kyoto Imp. Univ., Ser. B, 16 (1941).

23) Tokubo, J., Y. Ukai and S. Kakitani: Mineralogy and Geology, No. 4, (1950).

24) Takubo, J. and Y. Ukai : Mem. Coll. Sci, Kyoto Univ. Ser. B, 20, No. 20 (1952).

25) Takubo, J., Y. Ukai and Cheng Chi Kuo: Miner. Jour. 1, 25 (1953).

26) Takubo, J. and Y. Ukai : On the dispersion of dielectric constant, unpablished.

27) Thornton, W. M.: Prcc. Soc. London, (A), 82 (1909).

28) Tomita, T.: Jour. Geol. Soc. Japan, 44 (1942).

29) Tomita, T.: Jour. Geol. Soc. Japan, 45 (1943).

30) Umegaki, Y.: Mem. Coll. Sci., Kyoto Univ., Ser. B, 14 (1938).

31) Warren, B. C. and J. Bisoe: Zeit. Krist., 80 (1931).

32) Washington, H.S. und S. Kozu: Sci. Rep. Tohoku Imp. Univ., Ser. 2, No. 1 (1914).

33) Zizaimaru, S. J Jour. Geol. Soc. Japan, 42 (1940).

Manuscript received December 11, 1952 